\title{
RELATION BETWEEN SHORT-TERM AND LONG- TERM CONTRACTS ON THE ELECTRICITY MARKETS IN EUROPE
}

\author{
Dudić Branislav $^{1}$ \\ Dudić Zdenka \\ Janković Zoran ${ }^{3}$
}

\begin{abstract}
Usually, long-term prices on the power exchanges are on average higher compared to the short-term ones. It is possible to exploit this pattern when developing power market related trading strategies. Furthermore, if there is a way to establish situations in which premiums of forward and futures prices over spots are higher than usual, some revenue increasing possibilities for the market players are available. These issues are analyzed in this article on the example of Czech \& Slovak, German and Nordic electricity markets. Specific recommendations are also provided to the parties who trade on the electricity exchanges.
\end{abstract}

Keywords: electricity markets / electricity contracts trading / electricity exchange / risk premiums / electricity trading / pricing strategies.

1 University Business Academy, Faculty of Economics and Engineering Management, Cvećarska 2, 21000 Novi Sad, Republic of Serbia, e-mail: branislav.dudic@fimek.edu.rs and Comenius University, Faculty of Management, Odbojárov 10, 82005 Bratislava, Slovakia, e-mail: dudicbranko@yahoo.com

2 University Business Academy, Faculty of Economics and Engineering Management, Cvećarska 2, 21000 Novi Sad, Republic of Serbia, e-mail: zdenkadudic79@gmail.com

3 University Business Academy, Faculty of Economics and Engineering Management, Cvećarska 2, 21000 Novi Sad, Republic of Serbia 


\section{INTRODUCTION}

This article relates to the earlier works performed by different authors on the issues of relation between short-term and long-term prices on the electricity exchanges. New data has been considered in this study while older works have been updated with respect to the present market conditions. There are several different models addressing relations between the spot and futures prices of commodities. Generally, the main reasons why average futures and spot prices might differ are related to costs, benefits and risks of holding a commodity item. If it is beneficial to hold the product, futures prices decrease compared to the spot prices. The opposite is true if the product needs to be stored or looked after, which creates additional costs for the holder (Smolen, 2013). As it is not possible to store electricity, there is no need to discuss the benefits or costs of holding it. However, the issue of risk is more complex as risks of selling a product on a later date should be considered. In this article the issues of risk premiums of different contracts on the electricity markets are analyzed. These results are of crucial importance for the subjects producing and selling electricity on the markets. With correct price signals they can optimize their processes and become much more efficient.

\section{LITERATURE REVIEW}

When risk related asymmetry emerges between trading parties, the spot and futures prices are affected. If future risks are higher on the side of a seller than on the side of a buyer, futures prices are on average lower than spot (Smolen, 2013). The opposite is true if price risks faced by the buyer are more significant.

Power prices will in general be more of a factor on the top of the line than on the low end. With yearly normal prices of around 40 EUR/MWh, hourly spot prices of more than 1000 EUR/MWh have been seen on various European power markets amid past years (Smolen, Chen 2012). This further expands momentary risks for power buyers and discloses their relative hesitance to utilize the spot markets. (European Commission, 2019).

Therefore, it is expected that longer term contracts would be exchanged with certain premiums compared to the spot markets. 
This problem has been examined in various papers and reports analyzing the issue outlined. These papers have predominantly confirmed the theory described showing that the premiums were indeed observed on the electricity markets with the longer time contracts. These premiums were shown to be on the level of approximately 5\% for Nordic market (Botterud, Bhattacharyya, Ilic, 2002, Voronin, Partanen, 2012). For German market, the premiums observed were on the level of approximately 7\% (Moller, 2010, Redl, Haas, Huber, 2007, Redl, Bunn, 2011). Thorough works performed in publications analyzing periods of 2008-2012 found different premiums with different types of contracts and time to expiration for German, Nordic and Czech market (Smolen, 2012, Smolen, 2013). These premiums were also analyzed in perspectives of specific market conditions. Newer data will be analyzed in the forthcoming sections of this work.

\section{METHODOLOGY AND RESULTS}

The most important hypothesis being analyzed in this paper is that there are certain premiums on futures contracts compared to the spot prices in the power markets. This hypothesis has already been confirmed by different papers. However, the analysis performed in this work concentrates on later periods compared to previous authors. The second hypothesis concentrates on the existance of specific factors which could lead to the higher than average premiums on the futures markets. These hypotheses are examined in the part of this study devoted to the analysis of results.

The structure of this work is as follows: First, the price premiums of longer-term contracts during the last 5 years and their premiums compared to the spot prices are analyzed for German, Slovak and Nordic markets. In the next section, premiums of longer-term contract are analyzed with respect to specific situations on the market. This is performed to establish situations on the market when futures market premiums might be even larger than average. Lastly, conclusions and recommendations are summarized.

Various periods of expiration of different futures electricity contracts for different regions are compared in this part of this work. Figure 1. shows the premiums of monthly futures contracts over spot prices with different periods to expiration on the Czech PXE power exchange. 


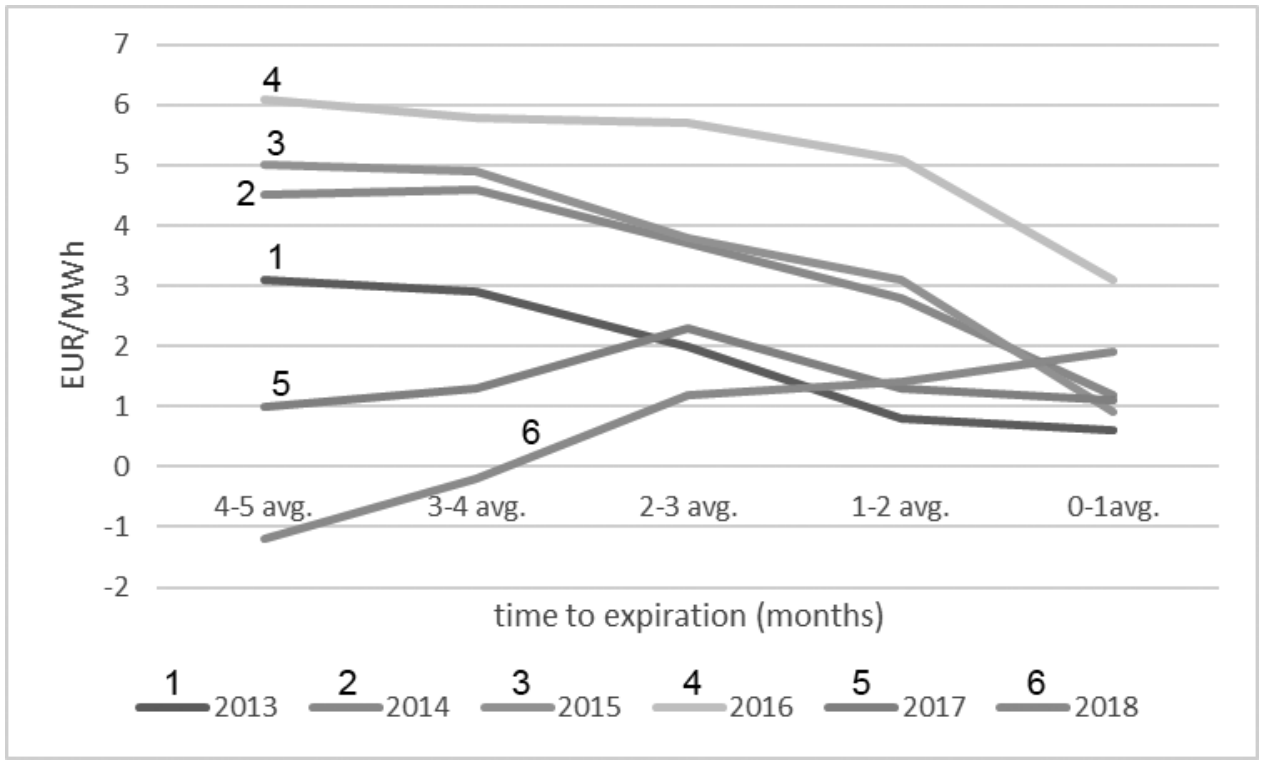

Data source: www.pxe.cz, www.ote-cr.cz (accessed: April, 2019)

Figure 1.: Czech PXE monthly futures vs. spot premiums (EUR/MWh) yearly averages of futures contracts vs. spot prices by time to expiration of futures contracts.

The hypothesis proposes that with longer periods to termination, exchanging futures contracts is related with higher dangers and accordingly premiums ought to be also higher. This is by all accounts affirmed by Figure 1. While shorter periods to termination of futures contracts show moderately stable premiums, the circumstances are altogether different considering longer periods to expiration. All things considered, exchanging futures contracts with brief time to expiration against spots would have been consistently profitable on the level of about 1.5 EUR/MWh with shorter time to expiration and on average 3 EUR/MWh with longer time to expiration of futures contracts. These data are further analyzed in Table 1. This table provides information also for peak load monthly contracts and quarterly base load contracts. These types of futures provide even higher premiums compared to the monthly baseload contracts. This confirms that contracts with higher risks show significantly higher premiums contrasted with the month to month baseload contracts. 
Table 1.: Czech market premiums of different contract types over spots (EUR/MWh), averages for 2013-18 period.

\begin{tabular}{|l|r|r|r|r|r|}
\hline future contracts & \multicolumn{6}{|c|}{ time to maturity (months) } \\
\hline & $4-5$ avg. & 3-4 avg. & 2-3 avg. & 1-2 avg. & $0-1$ avg. \\
\hline monthly baseload & 3.1 & 3.2 & 3.1 & 2.4 & 1.5 \\
\hline monthly peakload & 6.5 & 6.2 & 5.5 & 4 & 2.7 \\
\hline quarterly baseload & 3.5 & 3.5 & 3.3 & 2.9 & 2 \\
\hline
\end{tabular}

Data source: www.pxe.cz, www.ote-cr.cz (accessed: April, 2019)

Similar data were assembled for German market and the results are shown in Table 2. This table shows comparable results to the case of the Czech Republic. Quarterly baseload futures for the German market seem to be lower compared to the Czech Republic. This pattern is somewhat visible also for the other types of contracts.

Table 2.: German market premiums of different contract types over spots (EUR/MWh), averages for 2013-18 period

\begin{tabular}{|l|r|r|r|r|r|}
\hline future contracts & \multicolumn{6}{|c|}{ time to maturity (months) } \\
\hline & 4-5 avg. & 3-4 avg. & 2-3 avg. & 1-2 avg. & 0-1avg. \\
\hline monthly baseload & 3.3 & 3 & 2.8 & 2.3 & 1.2 \\
\hline monthly peakload & 6.3 & 6.3 & 6.1 & 3.9 & 2.5 \\
\hline quarterly baseload & 3.4 & 3.3 & 3.1 & 2.8 & 1.7 \\
\hline
\end{tabular}

Data source: energynet.dk, eex.com (accessed:April, 2019)

Table 3. provides similar analysis for the Nordic region, which is very specific with its high share of hydro-generation and its operated method as $70 \%$ of electricity is traded through the spot market (Voronin, Partanen, 2012).

Table 3.: Nordic quarterly futures vs. spot premiums (EUR/MWh) yearly averages of futures contracts vs. spot prices by time to expiration of futures contracts 2013-2017 period.

\begin{tabular}{|l|r|r|r|r|}
\hline future contracts & \multicolumn{4}{|c|}{ time to maturity (months) } \\
\hline & 3 months & 2 months & 1 months & last day \\
\hline yearly baseload & 3.2 & 2.7 & 1.9 & 1.5 \\
\hline
\end{tabular}

Data source: www.energinet.dk, reports - nasdaqomx.com (accessed: April, 2019) 
Table 3. also shows positive premiums for the futures market, however these seem to be lower compared to the Czech and German markets. Longer periods to expiration of the contracts also lead to higher premiums. Lower premiums in the Nordic region could also be affected by lower prices in this area.

Based on the results shown we can make the following conclusions about the premiums observed on the markets: There are certain premiums on the futures compared to the spot markets. This has been confirmed by many studies conducted for the previous periods and also by the findings presented in this study. Furthermore, these premiums follow certain regular patterns. The premiums are higher with the prospects of longer time spans of future contract length as well as with longer periods to termination.

The next part of this study concentrates on specific situations on the market when premiums can be even higher than the average premiums shown. If it is possible to find occurrences on the electricity markets, when premiums of forward and futures prices over spot prices are more significant, it can lead to possible profitable trading strategies on the electricity markets. In this paper we further analyze this issue on the example of the Czech and Slovak electricity markets. Large disparities exist among Member States, with some countries performing much better than others and well above the European average. Disparities exist in terms of the historical development of the area, population, population density, language, religion, system of education, social system or the actual growth potential of the state (Renkova, 2016). Cultural specifics, that limited for a long time the innovation activity in the Slovak Republic and Czech Republic and complicated the implementation of open innovation principles, should be overcome also in the field of human resources development (Stachová, Papula, Stacho, Kohnová, 2019). The elimination of regional disparities in Slovakia, but also in other Member States, was more difficult for several years due to the ongoing economic crisis. Its impact was noticeable only in the least economically advanced regions (Renkova, 2016). The analyzed hypothesis considers that the actual state of production portfolio on the market could have some impact on the spread between futures and spot markets. The analysis of related data is presented in the next section of this study. 


\section{PROPOSITION OF REVENUE ENHANCING STRATEGIES BASED ON THE ACTUAL STATE OF THE PRODUCTION PORTFOLIO AND DISCUSSION}

While costs on the power spot markets, for the most part depend on real supply, consumption and costs conditions, the equivalent cannot be said about the futures contracts as this market depends on expectations about future advancements instead of genuine information. The explanation on precisely how the forecasts are made by market players is sketchy and can be altogether different from case to case. With longer history, size and complexity of the market, the forecasts are of increased importance. Consequently, it is expected that prospects contracts prices on the CZ-SK market are overwhelmingly founded based on the situation in Germany and balanced for the standard spread between the markets observed. This speculation is upheld by data analysis, confirming that spreads between the German and Czech markets throughout the year usually do not fluctuate significantly.

This means that specific Czech and Slovak market information is presumably considered with only very little weight during the futures price formation mechanism. However, as spot prices are formed based on the relatively fully known market information, spot markets should reflect the actual market situation. One of the most crucial pieces of market information, which affects spot prices on the Czech and Slovak power market is the amount of nuclear capacities unavailable on the market. If futures prices are formed based on a stable spread with the German market, this means that spreads between futures and spot markets would be higher during the times when there is no nuclear maintenance on the Czech and Slovak electricity markets as this factor would further lower the spot prices, while its impact on futures contracts would be limited.

Table 4.: Impact of nuclear units' maintenance on spreads between futures and spot prices on the Czech and Slovak electricity market, Jan 2013 - Dec 2017 period. (3 months to the expiration of futures contracts)

\begin{tabular}{|l|r|r|r|r|r|}
\hline future contracts & \multicolumn{5}{|c|}{ Average monthly nuclear maintanance (MW) } \\
\hline & $0-100$ & $100-300$ & $300-600$ & $600-1000$ & over 1000 \\
\hline monthly baseload & 5.2 & 2.8 & 1.4 & 0.8 & 0.3 \\
\hline monthly peakload & 9.3 & 4.8 & 3.1 & 1.7 & 0.7 \\
\hline
\end{tabular}

Data source: www.energinet.dk, reports - nasdaqomx.com (accessed: April, 2019) 
Values shown in Table 4. confirm the hypothesis outlines. Spreads between futures and spot prices are indeed much higher in months when no nuclear maintenance is performed and lower in months when the large part of nuclear capacity is unavailable. Spreads of 5.2 EUR/MWh for monthly baseload contracts and 9.3 EUR/MWh for quarterly baseload contracts can be considered very significant and present substantial options to enhance profits of market players on the electricity markets.

\section{CONCLUSIONS}

In the first part of this work it was shown that futures contracts on the electricity markets are traded with certain premiums compared to the spot markets. These premiums are generally higher with longer times before expiration and with longer time frame of futures contracts. In the second part of this work, it was shown that nuclear maintenance is an important factor, which is at least partially neglected during the process of futures contracts price formation on the Czech and Slovak power markets. This factor leads to the higher spreads between futures and spot markets during periods when there are no nuclear plants maintenance on the Czech and Slovak power markets. During such periods it can be profitable for the market players to sell futures contracts with the intention to buy electricity on the spot markets afterwards. Such method would lead to very profitable trading strategies during the last 5 years.

Nevertheless, it should be mentioned that premiums of futures contracts during the last 5 years in European markets have decreased compared to the previous periods analyzed in papers written on similar subjects. The explanation for this could be in generally lower prices on the EU electricity markets. However, possible reasons can be also attributed to the fact that market structures are changing and with better interconnection and development of the markets futures prices premiums could decrease. This problem could be a subject of future analyses in this area. Another subject with significant implications for market players is the continuous analysis of market specifics which lead to higher than average futures contracts premiums.

As electricity markets in Serbia are not fully liberalized at present, the findings of this work are not applied to this country with contemporary market conditions. However, the process of electricity market 
liberalization will - in due time - probably also reach countries which are not currently members of the EU. If such a situation arrises, it will be interesting to compare futures contracts premiums in Serbia compared to the experiences from the EU region. It will also be crucial for market players to follow such issues closely to optimize their processes and face the challenges of the competitive market environment.

\section{REFERENCES}

1. 1. Botterud, A., Bhattacharyya, A., K., Ilic, M. (2002). Futures and spot prices - an analysis of the Scandinavian electricity market, (accessed 12. April 2019), Available at:

http://mit.edu/ilic/www/papers_pdf/futuresandspotprices.pdf

2. 2. Moller, CH. (2010). Balancing energy in the German market design, Dissertation, University of Karlsruhe, Germany.

3. 3. Redl, CH., Haas, R., Huber, C. (2007). Forward markets and their interactions with spot markets - an empirical analysis of the liberalised Europen electricity market (Accessed 10. April 2019), Available at: http://www.univie.ac.at/crm/simopt/Redl_paper_v1.pdf

4. 4. Redl, CH., Bunn, D., W. (2011). Determinants of the premium in forward contracts (accessed 5. April 2019), Available at: http://www.eeg.tuwien.ac.at/ eeg.tuwien.ac.at_pages/publications/ pdf/RED_PAP_2011_1.pdf

5. 5. Rentková, K., Mazanovský, M., Stanko, P., (2016). Increasing the competitiveness of European regions, Management in theory and practice, Praha, Newton College, p. 263-275.

6. 6. Rentková, K., Roštárová, M.,Mazanovský, M., (2016). The analysis of regional disparities in the Slovak republic, Vision 2020: innovation management, development sustainibility and competitive economic growth, IBIMA, Spain, p. 2014-2025.

7. 7. Smolen, J. (2013). Revenue management in electrity sector, International Journal of Arts and Sciences. - Vol. 6, No. 1, p. 519-532

8. 8. Smolen, J., Chen, Z. (2012). Analysis of price peaks on Danish electrity market, European Energy Market (EEM), IEEE,

9. 9. Smolen, J. (2012). Role of generating units' maintenance in forecasting electrity spot prices on Czech and Slovak electrity market, Manažment v teórii a praxi, Bratislava, Univerzita Komenského, R. Slovensko. 
10. 10. Stachová, K., Papula, J., Stacho, Z., Kohnová, L. (2019), External Partnerships in Employee Education and Development as the Key to Facing Industry 4.0 Challenges, Sustainability 2019, n.11, p. 345.

11. 11. Voronin, S., Partanen, J. (2012). A hybrid electricity price forecasting model for the Finnish electrity spot market (Accessed 20. April 2019), Available at:

http://www.forecasters.org/proceedings12/VORONINSERGEYISF2012.pdf

12. 12. European Commission. (2019). Overview of European Electricity Markets (accessed 14. April 2019), Available at:

https://ec.europa.eu/energy/sites/ener/files/documents/overview_of_e uropean_electricity_markets.pdf

\title{
ODNOS IZMEĐU KRATKOROČNIH I DUGOROČNIH UGOVORA NA TRŽIŠTIMA ELEKTRIČNE ENERGIJE U EVROPI
}

\author{
Dudić Branislav \\ Dudić Zdenka \\ Janković Zoran
}

Sažetak: Dugoročne cene na berzama električne energije u proseku su obično veće u odnosu na kratkoročne. Moguće je iskoristiti ovaj obrazac kada se razvijaju strategije trgovanja na tržištu električne energije. Štaviše, ako postoji način da se uspostave situacije u kojima su premije forvard i fjučers cena iznad spotova veće od uobičajenog, neke mogućnosti povećanja prihoda za tržišne igrače su dostupne. Ova pitanja su analizirana u ovom članku na primeru češkog $i$ slovačkog, nemačkog i nordijskog tržišta električne energije. Posebne preporuke su uvedene za one koje trguju na berzi električne energije.

Ključne reči: tržišta električne energije / trgovina električnom energijom / razmena električne energije / premije za rizik / trgovanje / strategije cena. 